\title{
The Effect of Teacher Certification and Work Motivation on Performance of Teachers PNS SD Negeri
}

\author{
Pertiwi Trisnawati ${ }^{1 *}$, Yasir Arafat ${ }^{2}$, Syaiful Eddy $^{2}$
}

\author{
${ }^{I}$ SD Negeri Plakat Tinggi \\ ${ }^{2}$ Universitas PGRI Palembang \\ *Corresponding author. E-mail: pertiwitrisnawati@gmail.com*
}

\begin{abstract}
Teacher certification can be interpreted as a process of acknowledging that a person has the competence to carry out educational services in a particular education unit, after passing a competency test conducted by a certification institution. This article aims to determine and to analyze the effect of teacher certification, and motivation from other outside of the teacher's personal internal. The teacher's personal internal inheritance was also very influential. Performance or achievement was that employee performance that was the result of work in carrying out a job. This research design used a quantitative research design. Data collection technique used questionnaires, observation, and documentation. The data analysis technique used qualitative analysis which includes data collection, data reduction, data presentation, drawing conclusions and verification. The results indicated that the variables of teacher compensation and job satisfaction affect teacher performance together. There was a significant effect of Teacher Certification and Work Motivation on Teacher Performance.
\end{abstract}

Keywords: Teacher Certification, Work Motivation and Teacher Performance

\section{INTRODUCTION}

Certification according to the Law of the Republic of Indonesia Number 14 of 2005 concerning Teachers and Lecturers Article 1 point 11 is the process of granting educator certificates for teachers and lecturers. Performance certification or achievement is that employee performance is the result of work in carrying out a job [1] The teacher is the provision of certification to teachers who have met the professional standards of teachers. The government hopes that from this certification program teacher performance will increase so that in the end the quality of education will also increase. There are still many teachers who have been certified but are not in accordance with the ability of a certified teacher or have achieved good teacher performance after being certified. The more the quality and professionalism of a teacher, the better the quality of the country. That is the general assumption of a country's education program.

Teachers who have high job satisfaction will work with enthusiasm, so as to provide opportunities to achieve high work results, School as a leader education organization that pays attention to aspects of teacher performance satisfaction. School as an educational institution or institution which is a place where the educational process is carried out has a complex and dynamic system [2] Teachers who have high professionalism will be seen from various aspects both in terms of pedagogical, professional and social competencies [3] Teacher certification is to get good and professional teachers, who have the competence to carry out the functions and goals of the school in particular, as well as educational goals in general, according to community needs and guidance from the Mulyasa era [4]

The role of certification, namely that teachers or lecturers better understand the rights and obligations in (Law No.14 / 2005 article 14 paragraph (1), among others; (1) earn an income above the minimum necessities of life and social welfare games; (2) get promotions and rewards according to with assignments and achievements work; (3) obtaining protection in carrying out duties and intellectual property rights; (4) obtaining opportunities to improve competence; (5) obtaining and utilizing learning facilities and infrastructure to support the smooth running of 
professional duties; (6) having freedom in providing assessments and participate in determining graduation, awards, and sanctions to students in accordance with educational principles, teacher code of ethics, and laws and regulations; (7) gain a sense of security and guarantee safety and carry out duties; (8) have the freedom to associate in professional organizations; (9) have the opportunity to play a role in determining educational policies; (10) have the opportunity to develop and improve academic qualifications and competencies; and (11) obtain training and professional development in their respective fields.

Teacher work motivation is an encouragement that can cause the teacher to do good or maximum to achieve the goals that have been set [5] Motivation can be interpreted as a driving force that has become active. Motives become active at certain times, especially when the need to achieve goals is felt. [6] The role of the teacher, especially performance motivation, in this case teaching, is very basic for a teacher. Motivation can arise from other things outside of the teacher's personal internal, but from the personal side of the teacher is also very influential. in individuals to carry out certain activities to achieve goals. If the work motivation is high, it will have an effect on high performance, on the other hand, if the motivation is low, it will cause the performance to be low. The certification fee received by the teacher for the responsibility that has been carried out is also a very important point in the motivation for the teacher's performance [7].

Teachers are human resource figures who occupy positions and play an important role in education. When everyone questions problems in the world of education, teacher figures must be involved in the discussion agenda, especially those concerning formal education issues [8]

The teacher is a job that requires very high professionalism from the teacher, any ideas or ideas in guiding students and in carrying out all their duties properly, according to direct observations in schools, work motivation and teacher performance today is very far from hope, the proof is that they come to school not on time, what's worse is that the teacher does not teach, they sit casually reading the newspaper, with work motivation and teacher performance just like that, the author is sure that until whenever education in Indonesia will never experience significant progress and our country will continue to be defeated by countries that are more advanced than us. Teacher performance is the teacher's willingness to carry out an activity and perfect it according to their responsibilities with the results as expected [9]. The rationale is that if the competence of the teacher is good followed by the income of the assignment, it is hoped that the performance is also good, if the performance of the teacher is good then the teaching and learning activities are also good, good teaching and learning is expected to produce education quality, that is the idea that teachers need certification.

\section{METHODS}

A research method is a series of methods or activities to carry out research based on basic assumptions, philosophical and ideological views, questions and issues at hand.[10] The research method has a specific research design. Talking about this type is no different than talking about evaluation problems.

Evaluating is nothing but obtaining data about the status of something is compared to a predetermined standard or measure, because evaluating is also measuring, [5] The method of this research is quantitative research by describing the research findings.

Quantitative research is based on the philosophy of positivism which emphasizes objective phenomena and is assessed quantitatively. The sample in this study was the SD Negeri in Plakat Tinggi District, with the sampling in this study using purposive sampling, namely the teachers who were used as research samples were teachers in each elementary school with a total sample of 55 teachers. In collecting data, techniques are needed, both techniques in providing data, and techniques in classifying the data that has been collected. The same thing was stated by [6] that the data collection method is a method used to collect data, while the data collection technique is the method used in carrying out the method that has been chosen by using questionnaire data and documentation. The data analysis technique in this study used simple correlation and multiple regression data analysis techniques with the help of the SPSS For Windows Version 22 program. The analysis implementation stage included: (1) descriptive analysis, (2) analysis requirements test, and (3) hypothesis testing.

\section{RESULTS AND DISCUSSION}

Hypothesis testing is continued after the data analysis requirements test is carried out, namely the normality test and then the hypothesis testing is carried out using the $t$ test and the F test, to determine the effect partially and simultaneously on the variables to be tested. 
a. Hypothesis Testing (H1) Test $\mathrm{f}$

Coefficients $^{\mathrm{a}}$

\begin{tabular}{|c|c|c|c|c|c|c|}
\hline \multicolumn{2}{|c|}{ Model } & \multicolumn{2}{|c|}{ Unstandardized Coefficients } & \multirow{2}{*}{$\begin{array}{l}\text { Standardized } \\
\text { Coefficients } \\
\text { Beta }\end{array}$} & \multirow[b]{2}{*}{$\mathrm{T}$} & \multirow[b]{2}{*}{ Sig. } \\
\hline & B & Std. Error & & & \\
\hline & $\begin{array}{l}\text { (Consta } \\
\text { nt) }\end{array}$ & $1,296 \mathrm{E}-13$ &, 411 & & ,000 & 1,000 \\
\hline & $\begin{array}{l}\mathrm{V}^{\text {VAR }} \\
\text { X2_TO } \\
\text { TAL }\end{array}$ & -100 & ,043 & -,102 & $-2,313$ & ,025 \\
\hline & 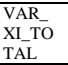 & 1,100 & ,044 & 1,101 & 24,918 & ,000 \\
\hline
\end{tabular}

Dependent Variable: X1 Dan $\mathrm{X}_{2}$

Based on the output above, it is known that the $\mathrm{t}$-test is 24.918 , because the t-value has been found, then the next step we will look for the t-table value. because the $t$ value of 24.918 is greater than 2.265 , so it can be concluded that Ho is rejected and $\mathrm{Ha}$ is accepted. Which means that there is an effect of teacher certification $(\mathrm{X} 1)$ on teacher performance $(\mathrm{Y})$

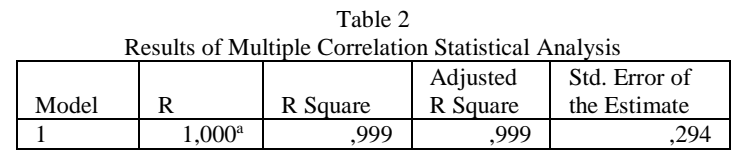

Based on multiple correlation analysis (R2) of 0.999, it means $99.0 \%$ of the X1 variable. While the rest (10099.0) $99.0 \%$ can be explained by other variables not examined in this study.

\section{b. Hypothesis Testing ( $\mathrm{t}) \mathrm{t}$ test}

Table 3. Result Test of Analysis Statistic Uji t Coefficients $^{\mathrm{a}}$

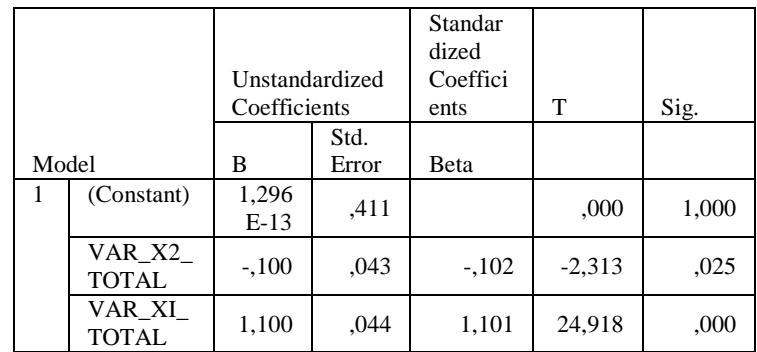

Dependent Variable: X1 Dan $\mathrm{X}_{2}$

Based on the output above, it is known that the $\mathrm{t}$ value is -2.313 , because the $\mathrm{t}$ value has been found. Then the next step we will look for the t table value, because the $t$ value of -2.313 is greater than 2.265 , so it can be concluded that $\mathrm{Ho}$ is rejected and Had been accepted, which means that there is an effect of work motivation (X2) on teacher performance (Y).

$$
\text { Table } 4
$$

\begin{tabular}{|l|r|r|r|rr|}
\multicolumn{7}{|c|}{ Results of Multiple Correlation Statistical Analysis } \\
\hline Model & \multicolumn{1}{|c|}{ R } & R Square & $\begin{array}{l}\text { Adjusted } \\
\text { R Square }\end{array}$ & \multicolumn{2}{l|}{$\begin{array}{l}\text { Std. Error of the } \\
\text { Estimate }\end{array}$} \\
\hline 1 & $1,000^{\mathrm{a}}$ &, 999 &, 999 & &, 294 \\
\hline
\end{tabular}

Based on the multiple correlation analysis (R2) of the Model Summary output, the R number is $0.999 \%$.
Since the multiple correlation value is between 0.20 0.999, it can be concluded that there is a low relationship between teacher certification and work motivation on teacher performance.

\section{c. Pengujian Hipotesis $\left(\mathrm{H}_{3}\right)$ Uji $\mathrm{f}$}

Table 5. Statistical Analysis Results Coefficients

\begin{tabular}{|l|l|r|r|r|r|r|}
\hline 1 & $\begin{array}{l}\text { Regressi } \\
\text { on }\end{array}$ & $\begin{array}{r}6340,48 \\
2\end{array}$ & 2 & 3170,241 & $\begin{array}{r}36633,8 \\
95\end{array}$ &, $000^{\mathrm{b}}$ \\
& Residual & 4,500 & 52 &, 087 & & \\
& Total & $\begin{array}{r}6344,98 \\
2\end{array}$ & 54 & & & \\
\hline
\end{tabular}

Dependent Variable: X1,X2, Terhadap Y

Based on the sig value for the effect of teacher certification (X1), work motivation (X2) on teacher performance $(\mathrm{Y})$ is $0.025<0.05$ and the $\mathrm{t}$ value is 2.313> t table 2.262, so it can be concluded that $\mathrm{H} 2$ is accepted which means there is an influence $\mathrm{X} 1, \mathrm{X} 2$ against $\mathrm{Y}$.

Table 6

Results of Multiple Correlation Statistical Analysis

\begin{tabular}{|l|r|r|l|l|}
\hline & & & & \\
Model & $\mathrm{R}$ & R Square & $\begin{array}{l}\text { Adjusted R } \\
\text { Square }\end{array}$ & $\begin{array}{l}\text { Std. Error of the } \\
\text { Estimate }\end{array}$ \\
\hline 1 & $1,000^{\mathrm{a}}$ &, 999 &, 999 & \multicolumn{1}{c|}{, 294} \\
\hline
\end{tabular}

R2 (Square Regression) Based on the output table spss multiple correlation, it is known that the coefficient of determination / Regression Square is 0.999. Together with the coefficient of determination is 0.999 or equal to $99.9 \%$, this number implies that the teacher certification variable (X1) and the work motivation variable (X2) simultaneously (together) affect the teacher performance variable (Y) by $00,9 \%$, while the rest $(100 \%-99.9 \%=0.01 \%)$ is influenced by other variables outside this regression equation / variables not studied.

Based on the results of the description of the research data analysis in CHAPTER IV using the SPSS program version 22. Before the research was carried out, the data requirements were tested first, namely the validity test and the reliability test. The data validity test was conducted by using the validation test which was carried out with the validator, namely PGRI Palembang University lecturers. Then proceed to test the validity of the analysis using the calculation of the SPSS version 22 program. The results of the calculation of the analysis validation for the principal's performance variables note that all of them are valid so that the statement items can be tested further. The results of the calculation of the analysis validation for the teacher 
performance variables note that all of them are valid so that the statement items can be tested further. The results of the validation analysis for the education quality variables note that all of them are valid so that the statement items can be tested further. Then the data prerequisite test is continued to the reliability test. After calculating using the SPSS version 22 program, it is known that the principal's performance variable obtained a value greater than the $r$ table, the teacher performance variable was greater than the $r$ table, and the education quality variable obtained a value greater than the $r$ table so it could be concluded that all research variables were declared reliable [7] [8].

\section{CONCLUSION}

Based on the results of the research that has been done, it can be concluded that Teacher Certification has an influence on the quality of education based on the results of the t test analysis. This shows that there is an effect of Teacher Certification on Teacher Performance in Elementary Schools in Plakat Tinggi District has answered the first hypothesis. Work motivation has an influence on teacher performance, based on the results of the $t$ test analysis. This shows that there is an effect of Teacher Motivation on Teacher Performance in Elementary Schools in Plakat Tinggi District has answered the second hypothesis. Teacher Certification and Work Motivation have a joint influence on the Quality of Education based on the results of the F test. This shows that there is an effect of Teacher Certification, Work Motivation simultaneously has an influence on Teacher Performance in Primary Schools in Plakat Tinggi District has answered the third hypothesis.

\section{REFERENCES}

[1] Arikunto, S. (2014). prosedur Penelitian Suatu Pendekatan Praktik. Jakarta:Rinika Cipta

[2] Diana, R. (2020). Pengaruh Motivasi Kerja dan Komunikasi Interpersonal terhadap Kinerja Guru. Jurnal endidkan Tambusai 4(3):1828-1835

[3] Firda, E., Arafat, Y., dan Wahidy, A. (2020). Pengaruh Tunjangan Profesi dan Disiplin Kerja terhadap Kinerja Guru. Dawuh Islamic Education Jurnal. 1(2):82-86

[4] Mulyasa, E. (2009). Menjadi Guru Profesional. Bandung: PT Remaja Rosdakarya

[5] Puspita, Y., Tobari., \& Kesumawati, N. (2021). Pengaruh Manajemen Kepala Sekolah dan Profesionalisme Guru Terhadap Kinerja Guru. Jurnal pendidikan, Kepemimpinan, dan Supervisi Pendidikan.6(1):88-99

[6] Umami, S., Lian, B., \& Missriani. (2021). Pengaruh Kepemimpinan dan Motivasi Kerja Guru terhadap disiplin Kerja. Jurnal Pendidkan, Kepemimpina, dan Supervisi Pendidikan. 6(1):5266

[7] Ristianey, F., Harapan, E., \& Destiniar. (2021). Pengaruh Sertifikasi Guru dan Motivasi Kerja terhadap Kinerja Guru. Jurnal Pendidkan, Kepemimpinan, dan Supervisi Pendidkan.6(1):3443

[8] Sardiman. (2007). Interaksi dan Motivasi Belajar Mengajar. Jakarta: PT Raja Grafindo Persada.

[9] Sugiyono. (2015). Metode Penelitan (Pendekatan Kuantitatif, Kualitatif, dan $R \& d$ ). Bandung:CV Alfabeta

[10] Sukmadinata, N. S. (2018). Metode Penelitian Pendidikan. Bandung :Remaja Rosdakarya 